\title{
Towards Consolidation: Civic Organizations and Democratic Values in Asia*
}

\author{
Lee, Sangmook (Yonsei University) \\ O zymy, Joshua (Sul Ross State University)
}

$\langle$ CONTENTS〉

I . Introduction

II. Civic Engagement and Democratic Values

1. India

2. Taiwan

3. South Korea

4. Bangladesh
5. Philippines

III. Data and Variables

1. Dependent Variable

2. Independent Variables

IV. Results

V. Discussion

- Keyword: Civic organizations, Democratic consolidation, Democratic values, Confidence in democratic institutions, Respect for pluralism

\section{【ABSTRACT】}

The factors affecting democratic consolidation have remained a constant research agenda for scholars across the globe. While sustainable economic conditions and free political institutions are thought to foster consolidation, there remains the question of what factors facilitate acceptance of democracy in the citizenry? Many contemporary scholars claim that civic associations are at the heart of a strong civil society which provides civic education leading to the internalization of democratic values in the citizenry. While this idea has been broadly tested and confirmed in the Western world there is little empirical research connecting civic organizations and democratic values in Asia. This may be due to cultural preconceptions that Asia is somewhat inhospitable to democratic consolidation or other factors. Can voluntary associations contribute to the development of

*Equal authorship. We would like to thank three anonymous reviewers for their helpful comments and suggestions. 
democratic values in Asia? This paper attempts to answer this by examining 5 Asian nations with varied histories of democratic consolidation: South Korea, India, Taiwan, Philippines, and Bangladesh. Using the World Values Survey (19951998), our findings suggest that civic organizations do in fact contribute to the enhancement of democratic values in Asia. However, there is a great amount of variation in this relationship. These findings demonstrate an increased need to study the connection between voluntary organizations and democratic values in Asia in greater detail.

\section{I . Introduction}

Since the mid 1970s the importance of democratic values and civil society for fostering those values has been emphasized in democratization movements all over the world. While democratic consolidation is a national level phenomenon it is nonetheless manifested in attitudinal orientations at the individual level. Scholars have examined the positive connection between democratic consolidation and the internalization, institutionalization, and habitualization of these democratic norms and values (Weigle and Butterfield 1992; Stokes 1993; Tismaneanu 1995).

Scholars increasingly note that the internalization of democratic values is important for democratic consolidation and civic education is important for the development of these democratic values and attitudes (Gibson et al 1992; Bratton et al 1999; Finkel et al 2000). As Finkel (2002: 994) rightly notes civic education must be thought to contribute to the acquisition of democratic values as Western countries have "devoted considerable resources over the past several decades to civic education as part of their larger efforts to provide democracy assistance and strengthen civil society in emerging democracies around the world." Scholars note that an active civil society is thought to play a pivotal role in not only opening democratic transitions, but also providing civic education and strengthening these democratic values which lead to consolidation (Diamond 1994; Linz and Stepan 1996). Many scholars worry that democratic consolidation may suffer when civil society is weakened (Arato and Cohen 1992; Nelson 1996).

The connection between civil society, civic education, and the development of democratic values can be traced in part back to Alexis De Tocqueville's (1969) argument that civic groups are one of the most important purveyors of civic education and citizen 
engagement in society. Robert Putnam has recently championed this idea emphasizing the positive effects of civic engagement and civic group involvement on developing democratic values. According to Putnam (1993), regions in Italy having high levels of voluntary associations have greater levels of social trust, there are more citizens who read newspapers, are interested in public affairs, and believe other citizens will act fairly and obey the law, as compared to regions lacking high levels of civic group memberships and strong social networks. He has extended these findings to the United States discovering similar trends (Putnam 1995, 2000).

Other scholars note that civic groups provide civic skills and opportunities to develop and utilize these skills, which is powerful form of civic education (Brady et al 1995; Verba et al 1995; Ayala 2000). These voluntary associations are thought to be especially important for educating citizens on aspects of civic and political affairs and mobilize them to participate in politics and civic life. As Verba et al (1995) note, these civic skills are usually acquired through compulsory education. However, when people lack such an education they turn to institutions in civil society, such as churches and other voluntary civic groups. So if there is a connection between civic education, democratic values, and democratic consolidation, voluntary associations may be at the heart of this relationship. One way in which to examine this relationship is to explore the connection between voluntary associations and the development of democratic values.

While many scholars have focused on this relationship in the context of Russia (Tismaneanu 1995), states of the former Soviet Union (Stokes 1993), Italy (Putnam 1993), and Central America (Booth and Richard 1998), little work has been done to examine this relationship in Asia. One of the reasons for such an omission may be related to the Asian cultural environment. According to Huntington (1991), Asia's Confucian culture may be an obstacle to future democratization, as well as other factors such as lack of experience with democracy and a weak commitment to democratic values held by political elites. Huntington (1991: 298) argues that "only Western culture provides a suitable base for the development of democratic institutions, and consequently that democracy is largely inappropriate for non-Western societies." Other scholars, by contrast, argue that cultural factors do not matter in the democratization of Asian countries (Di Palma 1991; Friedman 1994; Hetherington 1998).

Can voluntary associations contribute to the development of democratic values in Asia? In order to understand the role of civic organizations in democratic consolidation in Asia our approach is to examine their affect on changing individual level attitudinal orientations, such as democratic values. In this article we seek to help scholars answer this research question by examining five cases: South Korea, India, Taiwan, Philippines, 
and Bangladesh. These countries are selected as they have all had experiences with democracy for various periods of time and have experienced different levels of democratic consolidation. Furthermore, civic groups and civil society have played different roles within the democratization processes of these countries. Using the World Values Survey (1995-98) we examine the effects of voluntary group membership and other factors on democratic values in these countries. Findings suggest a wide range of variation between these countries ranging from no relationship, to positive relationships, to even negative relationships. We take broad strokes in examining this relationship and our findings suggest a greater need to examine the effects of voluntary associations on democratic values in Asia.

\section{II . Civic Engagement and Democratic Values}

How can civic group involvement lead to the development of democratic values? Since Tocqueville emphasized the importance of civic engagement to explain the source of the United State's stable democracy in the early 19th century, associational life has been regarded as an essential source for stable democracy to many neo-Tocquevillians. Civic groups help to develop the attitudes shift towards positive democratic values required for democratic consolidation. Civic association is hypothesized to produce a positive effect on civil society and democracy. Putnam, one of the most prominent of the neoTocquevillians who advances this argument, argues that civic associations provide a place where new ideas are invented, tested, and evaluated (Putnam 1993, 1995, 2000). An increase in civic organizations and social networks contribute to stable democracy by buffering social conflicts and promoting civic engagement. These organizations also play a role as an institution to educate people and encourage civic virtues such as tolerance, respect, and solidarity. Putnam argues that the quality of democratic politics and social life is highly dependent on the quality of people's associational life (Putnam 1993: 89-91, 1995: 65-67).

We define democratic values based on a three-fold classification, including confidence in government, rule of law, and respect for diversity or tolerance. Diamond (1999) demonstrates that this categorization is appropriate. He claims that the basic elements of what constitute democratic values include the rule of law, confidence in democratic institutions, and respect for pluralism. ${ }^{1)}$ Democratic values then loosely defined revolve

1) According to Diamond (1999), the quality of democracy can be regarded as a liberal democracy including the following elements: protection of individual rights, respect for a rule of law, accountability of 
around the level of perceived confidence individuals have in their political system, their respect for the rule of law as the appropriate rules of the game, and their respect for other persons regardless of their ideas and beliefs.

Voluntary organizations are hypothesized to produce democratic values by encouraging group members to interact with a broad range of people within their community and in their group. This produces inter-personal trust within the group which can be extended outside of the group to society as a whole. It also promotes democratic values such as tolerance, as well as generalized social trust (Putnam 2000). As Putnam (2000: 21) states, civic group involvement will produce "frequent interaction among a diverse set of people (which) tends to produce a norm of generalized reciprocity."

While scholars such as Putnam focus on the connection between civic group involvement, diverse social interaction, and the development of democratic values, other scholars place civic education at the heart of this relationship. Verba, Scholzman, and Brady's Voice and Equality (1995), outlines this basic argument. These authors argue that civic groups provide resources to members, which in turn mobilizes them to participate in civic and political affairs. Ayala (2000) notes that group mobilization can be either indirect or direct.

Indirect mobilization refers to the ability of groups to provide skills and experiences relevant to politics and civic affairs that would encourage engagement. Verba et al (1995) refer to these as "civic skills". Learning to write, speak in public forums, and engage in collaborative, democratic decision-making are skills that may not directly foster engagement, but lacking them is a barrier to participation.

Direct mobilization refers to the ability of group members to encourage each other to participate in collective group action. According to Pollock (1982), this involves members motivating other members to become involved. Rosenstone and Hansen (1993) argue that groups can encourage activism, because they encourage other members to participate.

This mobilization literature points to groups as providing an important source of adult civic education. Groups tend to encourage members to participate in the political process and in community affairs and give them the skills and encouragement to do so. Research indicates that involvement in civic groups and these forms of mobilization that occur therein is likely to be a powerful generator of civic education (Verba et al 1995; Ayala 2000).

Scholars testing the relationship between civic group involvement and democratic values have demonstrated many particularities in this relationship. Seligson (1999) 
examines the relationship between civ c association and democratic participation in six Spanish-speaking countries in Central America. He argues that democratic behavior depends on participation in different types of associations. According to him, although participation in community improvement associations is a consistent predictor of democratic behavior at an individual level, participation in other kinds of associations is not. Borgos and Douglas (1996) support Seligson's findings. They argue that community associations are more productive for the health of a democracy than others. Eastis (1998) argues that democratic norms and values may be produced in groups, but are strongly influenced by the group's organizational characteristics. Brehm and Rahn (1997) demonstrate that civic group involvement positively affects confidence in government, as well as interpersonal trust in the United States.

Both the neo-Tocquevillian thesis and the studies from the mobilization literature lead us to hypothesize a positive relationship between civic group membership and democratic values. Groups should provide the kind of experiences that foster civic education in the form of civic skills acquired and opportunities to utilize them within and outside of the group. They also promote democratic values such as tolerance through exposure to a diversity of social contacts as a result of group membership.

If governments fail to promote confidence and if groups do not expose people to a variety of social contacts, or have had little role in sustaining democratic conditions group membership will not necessarily have a positive effect on democratic values. We find this to be the case in more than one country in the analysis, where government corruption is rampant, ethnic cleavages are prevalent, or civil society has been stifled. Because of this we must augment our general hypothesis based on the political and social conditions of each region, as well as the role of civic groups in each society. Below we provide a brief summary of the social and cultural conditions of each country in the analysis and the role of civic groups in democratization. These factors may lead us to change our basic research hypothesis above.

\section{India}

India has a fairly long history of attempting to consolidate democracy. Having gained independence from the British in 1947, the county it has been dominated by the Congress party for most of its history (Gould 1980; Anderson 1991). However this domination by the Congress party has not resulted in full political stability. India has suffered inconsistencies in holding federal elections, emergency rule in the 1970s, the assassination of both Indira Gandhi in 1984, and the head of the party Rajiv Gandhi 
during the 1991 election (Chowdhury 1993). It has also experienced political violence through the Sikh seperationist movement in the province of Punjab into the mid 1990s.

These basic facts regarding the Indian political system bring into question the confidence of many Indian citizens of their political system. In a recent study of Indian democracy Chandra (2004) argues that India still contains elements of a patronage democracy. These factors might negatively impact citizen confidence in the Indian government.

Another concern is whether civic groups will help to promote democratic values in light of the social and political turmoil in the country, but also the prevalent religious and caste systems that have historically divided the country. If Putnam (2000) and others suggest that groups need to bring members into contact with a variety of persons to facilitate democratic values such as tolerance, such a rigid social structure may prevent the dissemination of such values within civic groups. Pai (2002) notes that a social transformation has not taken place in India, even in light of the fact that lower castes are gaining political power. Chandra (2004) also argues that ethnic parties are found to succeed in Indian politics based on caste appeals and their appeals to the vast amounts of ethnic groups in the country. Perhaps the greatest challenges to people preaching and internalizing democratic values are the caste and ethnic divisions in the country. Foley and Edwards (1997) argue that such diversity in civil society can contradict Putnam's claims. Such divisions may hamper the ability of voluntary social groups to preach such values as tolerance of other races, castes, and religious values. This paired with India's troubles with political violence and instability lead us to hypothesize a negative relationship between civic groups and democratic values in India.

\section{Taiwan}

Taiwanese democracy has taken quite a long time to develop. The critical moment of Taiwan's democratization was in 1987 when the ruling KMT (Kuomindang) party lifted martial law which had lasted for almost 40 years. In order to sustain the KMT regime's control in light of mounting opposition, Chiang Ching-kuo, head of KMT party, terminated his own party's authoritarian rule over the society. In 1996, the people of Taiwan directly elected their president. For the first time in Taiwan's political history a peaceful regime change occurred in 2000. An opposition party (the Democratic Progressive Party) was democratically elected into Taiwan's government. These recent events symbolize that democracy has come about in Taiwan, but it is a recent event.

Even with Taiwan's long history of military rule, the path to democracy has spawned a 
large increase in civic groups across the country. Since the 1980s, there has been a dramatic upsurge in the amount civic organizations in the country. According to Kuan (2006), about 75\% of the Taiwan's civic organizations were founded between 1980 and 2000 .

However, Taiwanese civil society was controlled by an authoritarian government monopolized the KMT for the majority of its history. The interventionist state left little room for civic organizations to grow. The Leninist party chose to employ a corporatist strategy to control major social groups, such as trade unions. Because of this legacy although Taiwanese civic organizations have grown rapidly in terms of quantity since the 1980s, their activities are not important politically.

As Kuan (2006) argues, Taiwan's organizational resources of civic groups are relatively weak. With regard to size of membership as an indicator of organization resource, many of Taiwan's civic groups are composed of a small number of members. According to Diamond (2001), Taiwan is a democratic country in terms of its Freedom House score (1 on political rights and 2 on civil liberties). However, it has still has severe problems to overcome for consolidation. One of them is widespread corruption in politics and government. And another is that party politics remaining substantially polarized along the lines of ethnicity (mainlander vs. Taiwanese) and attitudes toward the mainland (independence vs. unification). Institutional structure is another problem. Taiwan's constitutional system suffers from serious deficiencies and a lack of consensus in two of its most vital dimensions (the executive structure and the electoral system).

In sum, civic groups have not been a major party of Taiwanese civil society until the mid 1980s and their activities have not been connected to democratic consolidation. Because the context of transition to democracy in Taiwan was led from above, that civil society was strongly controlled by the Leninist party (KMT) for a long time, political corruption has been a lingering problem, and the prevalent political and ethnic cleavages that are predominant in Taiwanese society, we hypothesize no relationship between civic groups and democratic values in Taiwan.

\section{South Korea}

Korean civil society has steadily developed even under circumstances of coercive state power which maintained tight control over civil society. However, Korean civil society has contributed tremendously to the shift from authoritarianism to democracy in the country. This includes the explosive citizen demonstrations in June 1987, which resulted in the beginning of democratization (Lee 1993: 358-59). The urban middle class pressed 
their challenge to the authoritarian state as members of student movements, churches, professional associations, trade unions, and civic associations. In particular, during the 1980s, Korea's civil society grew significantly larger. With the economic success of Korea's business sector and a more liberal political environment, a pluralization of interests has manifested itself in many different arenas of social life. Many voluntary associations were created and the differentiation of social classes developed further, thereby engendering relatively distinct class identities and class-based interest groups, as well as a powerful working-class movement. However, Korea's ethnic homogeneity has prevented groups from being divided over ethnic cleavages.

Korean society has undergone a dramatic transformation since it transitioned to democracy in 1987. Unlike in Taiwan, civil society contributed greatly to opening up this democratic transition and also to democratic consolidation. Civic groups have penetrated many areas in Korean society before and after 1987. Given their importance in consolidating Korean democracy, Korea's positive experiences with democracy thus far, and a lack of strong ethnic cleavages in the country, we hypothesize a positive relationship between group membership and democratic values in Korea even in light of the recent history of such events.

\section{Bangladesh}

Bangladesh emerged as an independent country in 1971, but has struggled with democratic consolidation, political turmoil, and economic hardship. As Vajpeyi (1987: 316) notes, while the Bengalis of East Pakistan won independence with the intent of a democratic state, "the substance and style of politics- political assassinations, coups, and counter coups- did not change." Vajpeyi notes O'Donnell (1984: 261) who claims that Bangladesh has consistently, "vacillated between democracy and authoritarian rule." The transition to a democratic political system did not even formally begin until 1990 . Siddiquee (1999: 89) notes that bureaucratic accountability is very low in Bangladesh so that it has, "remained elitist in composition, narrow in outlook, insulated from the people and unresponsive to their desires. Not surprisingly, the level of consumer satisfaction is unusually low." These factors may negatively affect how confident Bengalis are in their political system.

Another factor which may influence confidence in government is the poor economic conditions that have been prevalent over time in Bangladesh. Studies demonstrate a connection between economic performance and citizen discontent with government (Anderson and Guillory 1997; MacCulloch 2004). Finkel and Muller (1998) note that while 
this can result in discontent it does not lead to outright rebellion. Finkel et al (1989) connect economic performance satisfaction to confidence in government.

Like Taiwan civic groups have yet to play an important role in the politics of Bangladesh. Siddique (1999: 94) also argues that civic groups have, "yet to emerge as a powerful force in Bangladesh.... Some of these groups have achieved some degree of success in a few areas. But such success stories are very limited and these groups face a range of problems." Because of the low status and importance of civic groups within the Bengali political system and the economic and political problems prevalent in the country we expect there to be no relationship between civic groups and democratic values in Bangladesh.

\section{Philippines}

The Philippines has struggled with democratic consolidation since its independence in 1946. Its modern political history has been marked with problems under Ferdinand Marcos, which included human rights violations, martial law, and political corruption. However, it has also been marked by strong student and protest movements including the now famous EDSA revolution of 1986, where the peaceful demonstrations of millions of protestors contributed to the downfall of Marcos's regime. However, political corruption, a poor economy, and emerging separatist movements plagued the country into the $1990 \mathrm{~s}$.

Grass-roots power and activism by civic groups in civil society seems relatively weak in the Philippines. Labor unions, church, and civic groups which have been a hallmark of the political scene have been declining. According to Murphy (1997: 5), democracy in the country is unfinished because, "the vast majority of citizens, especially poor ones, have no input in the electoral process. Surveys show that before the 1992 election no labor union, peasant, fisherman, or urban poor group had any say at all, or was even consulted in regard to who would be the candidates for president, the Senate, and the House of Representatives." He goes on to argue that, "the democracy that does exist provides an atmosphere helpful in many ways to the formation of strong peoples organizations with a political voice. It is still extremely difficult, however, to make organizations of this kind a reality." Because of their struggle for substantive democratic consolidation, problems with income inequality, and the relative weakness of civic groups within civil society over time, we do not expect any relationship between civic groups and democratic values in the Philippines. 


\section{Data and Variables}

This article tests the relationship between civic organizations and democratic values in Asia using the World Values Survey (1995-98). This data set which provide data from 91 nations throughout the world and is a rich source of data to test the relationship between civic engagement and democratic values in the five selected Asian countries. Although this data set contains 11 Asian countries, five countries are available to be included in the analysis due to data limitations in the other 6 countries.

\section{Dependent Variable}

The first consideration is the dependent variable in the analysis, which is democratic values. Scholars tend to conceptualize democratic values as generally including support for political institutions and a general respect for diversity or tolerance. Diamond (1999) claims that the basic elements of what constitute democratic values include the rule of law, confidence in democratic institutions, and respect for pluralism.

Public confidence in political institutions is thought to play a positive role in enhancing democratic stability. It makes political leaders more accountable and representative to the public. These democratic values are essential elements of modern democratic systems. ${ }^{2)}$ Researchers have used these concepts in an effort to estimate how much the public has democratic values and beliefs in given countries (Chanley, Rudolph, and Rahn 2000; Mishler and Rose 2001). While the public may not like their elected political leaders at any given time, support for their basic political institutions is important for the health of the democracy in the long-term.

As Linz and Stepan (1996) argue, respect for the rule of law is also vital element in consolidating democracy. When a healthy judicial branch checks public officials, ${ }^{3)}$ they

2) According to Roniger, public trust is one precondition for democratic consolidation in Latin American countries. See his article, "Public Trust and the Consolidation in Latin American Democracies," in Archibald Ritter, M. Cameron, D. Pollock, eds, Latin America to the Year 2000 (New York: Praeger, 1992). Hall and Shils also argue that public trust in government is an essential element of civility within a democratic civil society. John Hall, "The Nature of Civil Society," Society 35:4 (May/June 1998). Edwards Shils, "The Virtue of Civil Society," Government and Opposition 26-1 (Winter 1991).

3) According to O'Donnell, horizontal accountability by politicians is a criteria of democratic consolidation and needs to be based on the rule of law. See his article, "Horizontal Accountability in New Democracies," Conceptual and Normative Issues. Rose and Shin also argue that people's trust and support for democratic institutions and the rule of law are the most critical elements in new democracies. They argue that because new democracies have not sufficiently internalized these democratic values, they remain incomplete democracies or breakdown into authoritarian regimes. 
commit themselves to a consensus on the rules of the game. Public support for the legal system can be considered a democratic value, because individuals believe in the health of the legal system and the rule of law. When the public internalizes common sense values, respect for each other, and supports political institutions democracy has a chance to develop (Hetherington 1998). In this sense these factors such as confidence in political institutions, respect for the rule of law, and tolerance make up the core of the concept of democratic values.

We operationalize the concept of democratic values around the concepts of confidence in political institutions, respect for the rule of law, and tolerance of other person's viewpoints. To do so we use responses to the survey question, "I am going to name a number of organizations. For each one, could you tell me how much confidence you have in them?" Three institutions are named "the legal system, the police, and the government." The response categories are coded as: (4) a great deal (3) quite a lot (2) not very much (1) not at all.

We feel that confidence in the legal system adequately represents respect for the rule of law, and confidence in government represents respect for political institutions. We include a measure of confidence in the police, because attitudinal orientations can be affected by local level considerations. For example, Booth and Seligson (2005) note that measuring political legitimacy requires consideration of people's experiences with local government, rather than just national government.

Our measure of respect for diversity or tolerance is measured with the following survey question: "Please tell me which one comes closest to your own views:" The values were coded as: (1) To build good human relationships, it is most important to try to understand other's preferences (0) To build good relationships, it is most important to express one's preferences clearly. The confidence in government measures were collapsed into a dummy variable ( 1 and $2=1,3$ and 4=0) and are combined with the tolerance measure into an added index to measure democratic values. The dependent variable can range in value from 0-4. These measures are further listed in Appendix A.

\section{Independent Variables}

Involvement in civic groups is the main independent variable in the analysis. This is measured with membership in a variety of civic associations. A list of voluntary associations used in the World Values Survey includes 8 groups: church or religious organization, sport or recreation organization, art, music or educational organization,

See their article, "Democratization Backwards: The Problem of Third-Wave Democracies," British Journal of Political Science 31 (2001). 
labor union, political party, environmental organization, professional association, and, charitable organization. ${ }^{4)}$ Each measure is coded as a dummy variable (1) member (0) not a member.

Other factors are also controlled for in the analysis. First we control for social status, because scholars point out that higher status individuals are likely to be involved in civic groups (Brady et al 1995; Finkel 2002). We measure social status with the following question: "people sometimes describe themselves as belonging to the working class, the middle class, or the upper or lower class. Would you describe yourself as being to the:" We coded responses as follows: (5) upper class (4) upper middle class (3) lower middle class (2) working class (1) lower class.

We also control for age, as older persons are more likely to participate in civic groups and in politics (Putnam 2000; Verba et al 1995). Age is measured in actual years.

Political interest has been shown to be an important precursor to involvement in groups and other forms of political engagement (Pollock 1982; Mangum 2003). We control for political interest in the analysis with the following survey question: "How interested would you say you are in politics?" These values were coded as (4) very interested (3) somewhat interested (2) not very interested (1) not interested at all.

Gender and marital status are also considerations to control for in the analysis. As Putnam (2000) notes, marital status may detract from available time to participate in social groups. He also notes that women and men may participate in groups to varied degrees. We control for gender with a question measuring the sex of the respondent coded (1) male (0) female. Marital status is measured with a question asking respondents if they are married, which is coded as: (1) married (2) living together as married (3) divorced (4) separated (5) widowed (6) single.

\section{Results}

Do civic organizations positively impact democratic values in Asia? The results are estimated with multivariate regression models utilizing Huber-White Heteroskedastic error correction to match the properties of the dependent variable. Table 1 reports a general account of this relationship considering all five countries. For the most part

4) There may be a contradiction about including political parties as one of civic organizations. In general, political parties are located in the political society instead of civil society. However, they may also become one of source of civil society activity in many societies. See Sheri Berman, "Civil Society and Political Institutionalization," American Behavioral Scientist 40-5 (March/April 1997). 
some groups do tend to have some effect on democratic values. ${ }^{5}$ Charity and professional group membership facilitate democratic values, while sports group membership seems to depress it. Setting aside the question of statistical significance, group membership seems on the whole more likely to produce a positive rather than a negative effect on the dependent variable.

While Neo-Tocquevillians like Putnam and the mobilization literature predict a positive relationship between these variables, this is not always the case in these 5 Asian countries. Critics suggest that the diversity of civil society may impede the ability of groups to play the role the social capital thesis predicts (Foley and Edwards 1997). This is not necessarily found either. The best general assessment of these results is a mixed account supporting both sides in part. Groups may in fact provide the skills and diverse social contact in Asia that can bring citizens into contact with each other and provide a positive effect on democratic values. These factors can only be demonstrated indirectly in the analysis, but charity and professional groups seem to be good for the development of democratic values in Asia at least in our analysis herein. In this respect our initial hypothesis is partially confirmed in this analysis.

〈Table 1〉 Civic Association and Democratic Values in Asia

\begin{tabular}{l|c|c}
\hline \multicolumn{1}{c|}{ Variables } & \multicolumn{2}{c}{ Huber-White Regression Estimates } \\
\hline \multicolumn{1}{c|}{ Civic Groups } & B & SE \\
\hline Union & -.056 & $(.053)$ \\
Political party & .035 & $(.051)$ \\
Charity & .094 & $(.055)^{*}$ \\
Professional & .107 & $(.055)^{*}$ \\
Sports & -.109 & $(.045)^{* *}$ \\
Church & -.006 & $(.037)$ \\
Art & -.045 & $(.048)$ \\
\hline Controls & & \\
\hline Age & .006 & $(.001)^{* *}$ \\
Gender & .081 & $(.034)^{* *}$ \\
Political Interest & .139 & $(.034)^{* *}$ \\
Marital Status & -.039 & $(.037)$ \\
Social Status & .023 & $(.014)^{*}$ \\
Constant & 1.95 & $(.092)^{* * *}$ \\
\hline N: 5670 & \multicolumn{2}{|}{} \\
\hline
\end{tabular}

Note: ${ }^{*} \mathrm{p}<.10,{ }^{* *} \mathrm{p}<.05,{ }^{* * *} \mathrm{p}<.01$

5) Environmental group is dropped in the analysis to avoid a singularity. 
A majority of the control variables demonstrate a positive relationship with the dependant variable as well. Age, gender, political interest, and social status all have an effect on democratic values. These variables were selected primarily because older, higher status, and politically interested individuals have all been shown to participate more in politics and groups than their counterparts.

The political and socio-economic contexts of these five nations are very different, as are their experiences with democracy. Because of this it is imperative for us to look at the relationship between civic groups and democratic values on a case by case basis. As would be expected, mixed results found in the general model are also prevalent in each country. These results are presented in Table 2.

Beginning with South Korea, civic group membership has little effect on facilitating democratic values. The exception to this rule is with church group membership that has a positive effect. These results bodes well with the findings of Verba et al (1995) who demonstrate that church groups provide many opportunities for civic education and both civic and political participation. However, while age and gender have a positive effect on the dependent variable, socio-economic status is negatively related to the dependent variable. Our hypothesis is partially confirmed in the analysis. Only one group is related to democratic values, but this relationship is positive.

〈Table 2〉 Civic Association and Democratic Values Separated by Country

\begin{tabular}{|c|c|c|c|c|c|c|c|c|c|c|}
\hline \multirow{3}{*}{$\begin{array}{c}\text { Variables } \\
\text { Civic Groups }\end{array}$} & \multicolumn{10}{|c|}{ Huber-White Regression Estimates } \\
\hline & \multicolumn{2}{|c|}{ South Korea } & \multicolumn{2}{|c|}{ Taiwan } & \multicolumn{2}{|c|}{ Bangladesh } & \multicolumn{2}{|c|}{ Philippines } & \multicolumn{2}{|c|}{ India } \\
\hline & $\mathrm{B}$ & $S E$ & $B$ & SE & $B$ & $S E$ & $B$ & SE & $B$ & SE \\
\hline Union & -.052 & $(.134)$ & .003 & $(.121)$ & -.029 & $(.133)$ & .111 & $(.141)$ & -.201 & $(.098)^{* *}$ \\
\hline Political Party & .080 & $(.132)$ & .009 & $(.153)$ & -.047 & $(.097)$ & .237 & $(.146)$ & .022 & $(.099)$ \\
\hline Charity & -.075 & $(.116)$ & -.248 & $(.230)$ & .116 & $(.105)$ & .245 & $(.154)$ & .341 & $(.099) * *$ \\
\hline Professional & .147 & $(.102)$ & .302 & $(.230)$ & .176 & $(.123)$ & .164 & $(.120)$ & -.139 & (.125) \\
\hline Sports & -.052 & $(.088)$ & -.104 & $(.161)$ & -.073 & $(.097)$ & .053 & (.113) & -.136 & $(.096)$ \\
\hline Church & .164 & $(.078)^{* *}$ & .176 & $(.124)$ & -.109 & $(.084)$ & -.003 & $(.090)$ & -.267 & $(.077)^{* *}$ \\
\hline Art & -.024 & $(.093)$ & .016 & $(.213)$ & -.041 & $(.093)$ & -.142 & $(.142)$ & .187 & \\
\hline Controls & & & & & & & & & & $(.092)^{* * *}$ \\
\hline Age & .023 & $(.003) * *$ & .009 & $(.004)^{* * *}$ & .011 & $(.003)^{* *}$ & -.003 & $(.003)$ & -.005 & $(.003)^{* * *}$ \\
\hline Gender & .182 & $(.080) * *$ & .244 & $(.104)^{* *}$ & .009 & $(.081)$ & -.017 & $(.073)$ & -.025 & $(.068)$ \\
\hline Political Interest & .003 & $(.080)$ & .102 & $(.103)$ & .184 & $(.077)^{* *}$ & .186 & $(.073)^{* *}$ & .222 & $(.067)^{* * *}$ \\
\hline Marital Status & .019 & $(.072)$ & -.105 & $(.125)$ & -.109 & $(.090)$ & -.123 & $(.080)$ & -.067 & $(.081)$ \\
\hline Social Status & -.086 & $(.044)^{*}$ & .029 & $(.056)$ & .080 & $(.028)^{* *}$ & .018 & $(.034)$ & .037 & $(.021)^{*}$ \\
\hline Constant & 1.38 & $(.238)$ & 1.86 & $(.293)^{* *}$ & 1.93 & $(.217)^{* *}$ & 2.39 & $(.196)^{* *}$ & 2.30 & $(.167)^{* *}$ \\
\hline $\mathrm{N}$ & & 213 & & 557 & & 323 & & 146 & & 331 \\
\hline
\end{tabular}

Note: $* \mathrm{p}<.10,{ }^{* *} \mathrm{p}<.05$ 
We find no evidence of a relationship between civic group membership and democratic values in Taiwan. We expected this initially. Taiwan has not had a long history of an active civil society being involved in the democratization process. Like in South Korea age and gender are positively connected to democratic values. Social status, on the other hand, produces the opposite effect.

We also confirm our expectations in the third model for Bangladesh. Democratic values are not related to group membership. We do see positive relationships between the dependent variable and political interest, age, and social status. A similar relationship is uncovered in the Philippines, however only political interest is positively related to the dependent variable.

Perhaps the most robust relationship between civic groups and democratic values is found in India. While we hypothesized a negative relationship here, this is only uncovered with church and labor unions. Art and charity groups have a positive relationship with the dependent variable. Unlike the findings in other countries younger persons are more likely to exhibit democratic values. Like in Bangladesh politically interested and higher status individuals are more likely to hold democratic values than their low interest, lower status counterparts.

Overall our hypotheses are mostly confirmed in the analysis. Civic groups can affect democratic values in some countries, but they can also have no effect or produce a negative effect on such values as confidence in government, the rule of law, and respect for diversity. We attribute this to the varied economic, political, social, and cultural conditions in each country and how they have played into the unique aspects of civil society within each country. Overall, these results point us to the importance of considering such aspects when examining the relationship between groups and democratic values across countries.

\section{Discussion}

Drawing a simple connection between membership in civic organizations and democratic values does not fit well within the five Asian countries in the study. Instead, different types of civic organizations affect democratic values, and do so in different ways. Not all group memberships influence democratic values, but this is only one aspect. The other is that some memberships may actually depress democratic values.

One possible reason for this may be economic in nature. Although active civic participation may have been strong at various points in time in Bangladesh and the 
Philippines, they are not connected to democratic values in the analysis. Economic issues like low socio-economic development, rigid class structures, and a large gap between the poor and rich could constrain people's democratic values. Poor economic conditions can lead to dissatisfaction with government and can threaten public support for new democracies. Both of these are issues in Bangladesh and the Philippines where rampant social inequality may produce deep social cleavages. Noticeably, social status is positively associated with democratic values in Bangladesh and India in the analysis, which may point to the possibility that those occupying the lower rungs of the economic ladder are disenchanted and feel betrayed by their political system. Furthermore, in India where social mobility is routinely stifled, many civic groups that have an effect on democratic values produce a negative effect

Citizens have little incentive to trust government if their political system fails to provide for their basic needs and produce a baseline amount of opportunities for social mobility. In contrast, although both South Korea and Taiwan have achieved a high level of economic development compared to other countries, their economic development does not simply provide an environment that fosters a relationship between civic association, political trust, and democratic values. The role of the state is an important facilitating factor for deepening democratic values.

The Indian state has encouraged civic organizations to become actively involved in non-political issues including environmental, economic development programs, education, health service, and charity in recent years (Salamon and Anheier 1996). We find in this vein that charity and art group membership are both related to democratic values in India, but not in any of the other countries in the study. Because the Indian government promotes social welfare programs, citizens can take advantage of these resources and to some extent, trust their government. Thus, it may be no surprise that civic association has the greatest effect on democratic values in India versus countries such as the Philippines. Even though overall economic development and social mobility are low in India, the government may attempt to fill these gaps and garner public trust through recent social welfare programs.

Religious association is also important in the analysis. However, it also brings out a two-fold problem with civil society and tolerance. This can be seen by comparing South Korea to India. Religion is not homogeneous in South Korea, but religions are fairly tolerant of one another. Buddhists and others in the majority are fairly tolerant of the various Christian sects there. This helps to explain why church membership is positively related to tolerance in the paper. The other side of this issue is evident in India, where major religions are at odds with each other. Hindu majorities and Muslim minorities 
often clash over not only cultural beliefs and practices, but over political representation. These conflicts may help to explain the negative relationship between church membership and tolerance in India versus the positive relationship found in South Korea.

Overall, civic association can affect democratic values and confidence in government, but this relationship is contingent on multiple factors. Chiefly among these may be the social and cultural environment in a country and the role the state plays in civil society. Societies divided on religious lines may be unlikely to find common ground in civic groups, just as those that have large amounts of inequality.

So while inequality and conflict can stifle civil society, so can government. It is up to those active in civil society to promote common goals and cooperation, but it is also incumbent on government to allow space for civic cooperation to develop and provide resources to assist this development. This relationship is reciprocal. If governments want citizens to abide by the rule of law and trust in their elected officials, government must also provide certain resources to citizens to expect these democratic values. Democracy is always an experiment, but it seems that if government fulfills its part of the bargain, civic associations aid in helping citizens understand their part as well. 


\section{Appendix A: Construction of Dependent Variable}

The World Values Survey asks questions about confidence in political institutions as well as pluralism. For the democratic attitude index 4 variables are combined. One is related to pluralism and the other three variables are associated with confidence in governmental institutions such as legal system, police, and government. First, the survey question for pluralism is:

\section{"Please tell me which one comes closest to your own views."}

1. To build good human relationships, it is most important to try to understand other' s preferences

2. To build good relationships, it is most important to express one's preferences clearly

Second, the questions for trust in institutions are built on the following and are made into dummy variables and indexed with the pluralism measure.

"I am going to name a number of organizations. For each one, could you tell me how much confidence you have in them."

V6: The Legal System

1. A Great Deal

V7: The Police

2. Quite a Lot

V8: The Government

3. Not very Much

4. Not at All

Source: World Values Survey, 1995-1998 


\section{REFERENCES}

Anderson, Christopher and Christine Guillory, "Political Institutions and Satisfaction with Democracy: A Cross-National Analysis of Consensus and Majoritarian Systems," American Political Science Review 91 (1997).

Anderson, Walter K., "India's 1991 Elections: The Uncertain Verdict," Asian Survey 31 (1991).

Arato, Andrew and Jean Cohen, Civil Society and Democratic Theory, (Cambridge, Mass: MIT Press), 1992.

Ayala, Louis J., "Trained for Democracy: The Differing Effects of Voluntary and Involuntary Organizations on Political Participation,” Political Research Quarterly 53 (2000).

Berman, Sheri, "Civil Society and Political Institutionalization," American Behavioral Scientist 40 (1997).

Booth, J. and P. B. Richard, "Civil Society and Political Context in Central America," American Behavioral Scientist 42 (1998).

Booth, John A and Mitchell A. Seligson, "Political Legitimacy and Participation in Costa Rica: Evidence of Arena Shopping," Political Research Quarterly 58 (2005).

Borgos, Seth and Scott Douglas, "Community Organizing and Civic Renewal: A View from the South," Social Policy 27 (Winter 1996).

Brady, H. E., S. Verba, and K.L. Scholzman, "Beyond SES: A Resource Model of Political Participation,” American Political Science Review 89 (1995).

Bratton, Michael, "Political Participation in a New Democracy: Institutional Consideration from Zambia,” Comparative Political Studies 32 (1995).

Brehm, J. and W. Rahn, "Individual-Level Evidence for the Causes and Consequences of Social Capital," American Journal of Political Science 41 (1997).

Chandra, Kanchan, Why Ethnic Parties Succeed: Patronage and Ethnic Head Counts in India, (New York: Cambridge University Press), 2004.

Chanley, Virgina, Thomas Rudolph, and Wendy Rahn, "The Origins and Consequences of Public Trust in Government," Public Opinion Quarterly 64 (2000).

Chowdhury, Abdur R., "Political Surfing over Economic Waves: Parliamentary Election Timing in India," American Journal of Political Science 37 (1993). 
De Tocqueville, Alexis, Democracy in America, (San Francisco: Harper and Row), 1969. Di Palma, To Craft Democracies: An Essay on Democratic Transitions, (Berkley: University of California Press), 1991.

Diamond, Larry, "How Democratic is Taiwan? Five Key Challenges for Democratic Development and Consolidation," memo (2001).

Diamond, Larry, "Rethinking Civil Society: Toward Democratic Consolidation," Journal of Democracy 5-3 (1994).

Diamond, Larry, Developing Democracy toward Consolidation, (Baltimore: Johns Hopkins University Press), 1999.

Eastis, Carla, "Organizational Diversity and the Production of Social Capital," American Behavioral Scientist 42-1 (September 1998).

Finkel, Steven and Edward Muller, "Rational Choice and the Dynamics of Collective Political Action: Evaluating Alternative Models with Panel Data," American Political Science Review 92 (1998).

Finkel, Steven E., "Civic Education and the Mobilization of Political Participation in Developing Democracies," Journal of Politics 64 (2002).

Finkel, Steven E., Christopher A. Sabatini, and Gwendolyn G. Bevis, "Civic Education, Civil Society, and Political Mistrust in a Developing Democracy: The Case of the Dominican Republic," World Development 28 (2000).

Finkel, Steven, Edward Muller, and Mitchell Seligson, "Economic Crisis, Incumbent Performance, and Regime Support: A Comparison of Longitudinal Data from West Germany and Costa Rica,” British Journal of Political Science 19 (1989).

Foley, M. and B. Edwards, "Escape from Politics? Social Theory and Social Capital Debate," American Behavioral Scientist 40 (1997).

Freedom House, Annual Survey of Freedom Country Ratings: 1972-1973 to 1999-2000.

Friedman, Edward, ed., The Politics of Democratization: Generalizing East Asian Experiences, (Boulder, CO: Westview Press), 1994.

Gibson, James L., Raymond Duch, and Kent Tedin, "Democratic Values and the Transformation of the Soviet Union,” Journal of Politics 54 (1992).

Gould, Harold A., "The Second Coming: The 1980 Elections in India's Hindi Belt," Asian Survey 20 (1980).

Hall, John, "The Nature of Civil Society," Society 35-4 (May/June 1998).

Hetherington, Marc, "The Political Relevance of Political Trust," American Political Science Review 92 (1998). 
Huntington, S., The Third Wave, (OK: University of Oklahoma Press), 1991.

Kuan, Hsin-chi, "Civic Organizations in Hong Kong and Taiwan," working paper exerted from website〈http://www.cuhk.edu.hk/gpa/hckuan/work2.htm〉, (2006).

Lee, S. H., "Transitional Politics of Korea, 1987-1992: Activation of Civil Society," Pacific Affairs 66 (1993).

Linz, J. and A. Stepan, "Toward Consolidated Democracies," Journal of Democracy 7-2 (1996).

MacCulloch, Robert, "The Impact on Income on the Taste for Revolt," American Journal of Political Science 48 (2004).

Mangum, Maurice, "Psychological Involvement and Black Turnout," Political Research Quarterly 56 (2003).

Mishler, William and Richard Rose, "What are the Origins of Political Trust?: Testing Institutional and Cultural Theories in Post-Communist Societies," Comparative Political Studies 34-1 (February 2001).

Murphy, Denis, "Wanted: Both Democracy and Theology of Liberation," America 176 (1997).

Nelson, Daniel N., “Civil Society Endangered," Social Research 63 (1996).

O’ Donnell, Charles P., Bangladesh: Biography of a Muslim Nation, (Boulder: Westview Press), 1984.

O’ Donnell, Guillermo, "Horizontal Accountability in New Democracies," Journal of Democracy (July 1998).

Pai, S., Dalit Assertion and the Unfinished Democratic Revolution: The Bahujan Samaj Party in Uttar Pradesh, (New Delhi: Sage), 2002.

Pollock, Phillip. H., "Organizations as Agents of Mobilization: How Does Group Activity Affect Political Participation?” American Journal of Political Science 26 (1982).

Putnam, Robert, “Bowling Alone: America's Declining Social Capital," Journal of Democracy 6 (1995).

Putnam, Robert, Bowling Alone, (NY: Simon and Schuster), 2000.

Putnam, Robert, Making Democracy Work: Civic Traditions in Modern Italy, (Princeton: Princeton University Press), 1993.

Roniger, Luis, "Public Trust and the Consolidation of Latin American Democracies," in A. Ritter, M. Cameron, D. Pollock, eds., Latin America to the Year 2000, (NY: Praeger), 2000. 
Rose, Richard and D. C. Shin, "Democratization Backwards: The Problem of ThirdWave Democracies," British Journal of Political Science 31 (2001).

Rosenstone, Steven .J. and John M. Hansen, Mobilization, Participation, and Democracy in America, (New York: Macmillian), 1993.

Salamon, Lester and Helmut Anheier, The Emerging Nonprofit Sector: An Overview, (New York: Manchester University Press), 1996.

Seligson, Amber, "Civic Association and Democratic Participation in Central America: A Test of the Putnam Thesis," Comparative Political Studies 32-3 (May 1999).

Shils, Edwards, "The Virtue of Civil Society," Government and Opposition 26-1 (Winter 1991).

Shin, Myungsoon, "Confidence in Public Institutions and Democracy in South Korea," Korea Observer 37 (2006).

Siddiquee, Noore Alam, "Bureaucratic Accountability in Bangladesh: Challenges and Limitations," Asian Journal of Political Science 7 (1999).

Stokes, Gale, The Walls Came Tumbling Down: The Collapse of Communism in Eastern Europe, (NY: Oxford University Press), 1993.

Tismaneanu, Vladimir, Political Culture and Civil Society in Russia and the New States of Eurasia, (Armonk, NY: M.E. Sharpe), 1995.

Vajpeyi, Dhirendra, Book Review of Biography of a Muslim Nation by Charles Peter O’ Donnell, Journal of Politics 49 (1987).

Verba, Sidney, Kay L. Schlozman, and Henry E. Brady, Voice and Political Equality, (MA: Harvard University Press), 1995.

Weigle, Marcia A. and Jim Butterfield, "Civil Society in Reforming Communist Regimes: The Logic of Emergence," Comparative Politics 25 (1992). 